\title{
HYDROGEOCHEMICAL PROPERTIES PROVIDING LINKS TO METHANOGENESIS IN DEEP AQUIFER OF BHOLA ISLAND, BANGLADESH
}

\author{
MASUMA CHOWDHURY ${ }^{1 *}$, SARMIN SULTANA ${ }^{1}$, MD. ATIKUL ISLAM ${ }^{2}$, \\ AZIZ HASAN $^{1}$ AND KAZI MATIN UDDIN AHMED ${ }^{1}$ \\ ${ }^{I}$ Department of Geology, University of Dhaka, Dhaka-1000, Bangladesh \\ ${ }^{2}$ Department of Oceanography, University of Dhaka, Dhaka-1000, Bangladesh
}

\begin{abstract}
This paper compares the hydrogeochemical signatures between naturally flowing wells with methane (FWs) and non-flowing wells (require pumping) without methane (NFWs) by analyzing a total of 59 groundwater samples to find possible links for methane gas generation. Relatively higher concentration of $\mathrm{HCO}_{3}{ }^{-}$indicates oxidation of organic matter $(\mathrm{OM})$ for both the cases which is corroborated by the dominance of $\mathrm{Na}-\mathrm{Mg}-\mathrm{HCO}_{3}$ and $\mathrm{Na}-$ $\mathrm{Mg}-\mathrm{HCO}_{3}-\mathrm{Cl}$ water type. Low concentrations of redox sensitive parameters i.e., $\mathrm{NO}_{3}$, $\mathrm{SO}_{4}^{2-}, \mathrm{Fe}^{2+}$ and $\mathrm{Mn}^{2+}$ are indicating prevalence of extremely reducing condition and relatively lower concentrations of $\mathrm{SO}_{4}{ }^{2-}$ in $\mathrm{FWs}$ suggest microbial sulphate reduction reaching final stage of redox ladder i.e., methanogenesis. Comparatively higher temperature and subsequent higher electrical conductivity (EC) in FWs possibly attributed by the chemical reactions of methane generation or vice versa. Low geothermal gradient, presence of $\mathrm{OM}$ and distribution of the FWs over a paleo valley in the deep confined aquifer zone refer to the existence of favourable environment for biogenic methane production rather than the upward migration or leakage of thermogenic gas from the reservoir below.
\end{abstract}

Key words: Methane gas, Deep tubewells, Deep aquifer, Hydrogeochemistry, Methanogenesis

\section{Introduction}

Presence of methane gas in the water wells is not uncommon and many parts of the world have been reported to have microbial methane gas in water wells including Canada, United States, Denmark, Gulf of Mexico, Russia, East of China (Ridgeley et al. 2001, Molofsky et al. 2016, Bernerd et al. 1976, Delaune et al. 1986, Zhang et al. 2008, Kulongoski et al. 2018). Biogenic methane is frequently occurred at shallow depth $(10-100 \mathrm{~m})$ in the recent fluvio-deltaic plains of Bangladesh where extremely reducing condition prevails (Ahmed et al. 1998, Hoque et al. 2003). Interestingly unlike other parts of the country, Bhola district is unique in the context of water well methane gas occurrence due to its presence in the household deep tube wells specifically in FWs installed between $260 \mathrm{~m}$ and $295 \mathrm{~m}$ depth of the aquifer zone which sits on the Shahbazpur anticline, a mega-reserve of thermogenic gas (Imam 2015) and non-coexistence with highly saline groundwater (Ahmed et al. 1998).

*Author for correspondence: <m.chowdhury@du.ac.bd>. 
These deep tube wells are the only source of water which provide quality drinking water to local people (EC<1 mS/cm) (BWDB 2013) as shallow tube wells (depth<35 m) are unusable due to presence of high salinity (EC $\sim 8 \mathrm{mS} / \mathrm{cm}$, according to field investigation).

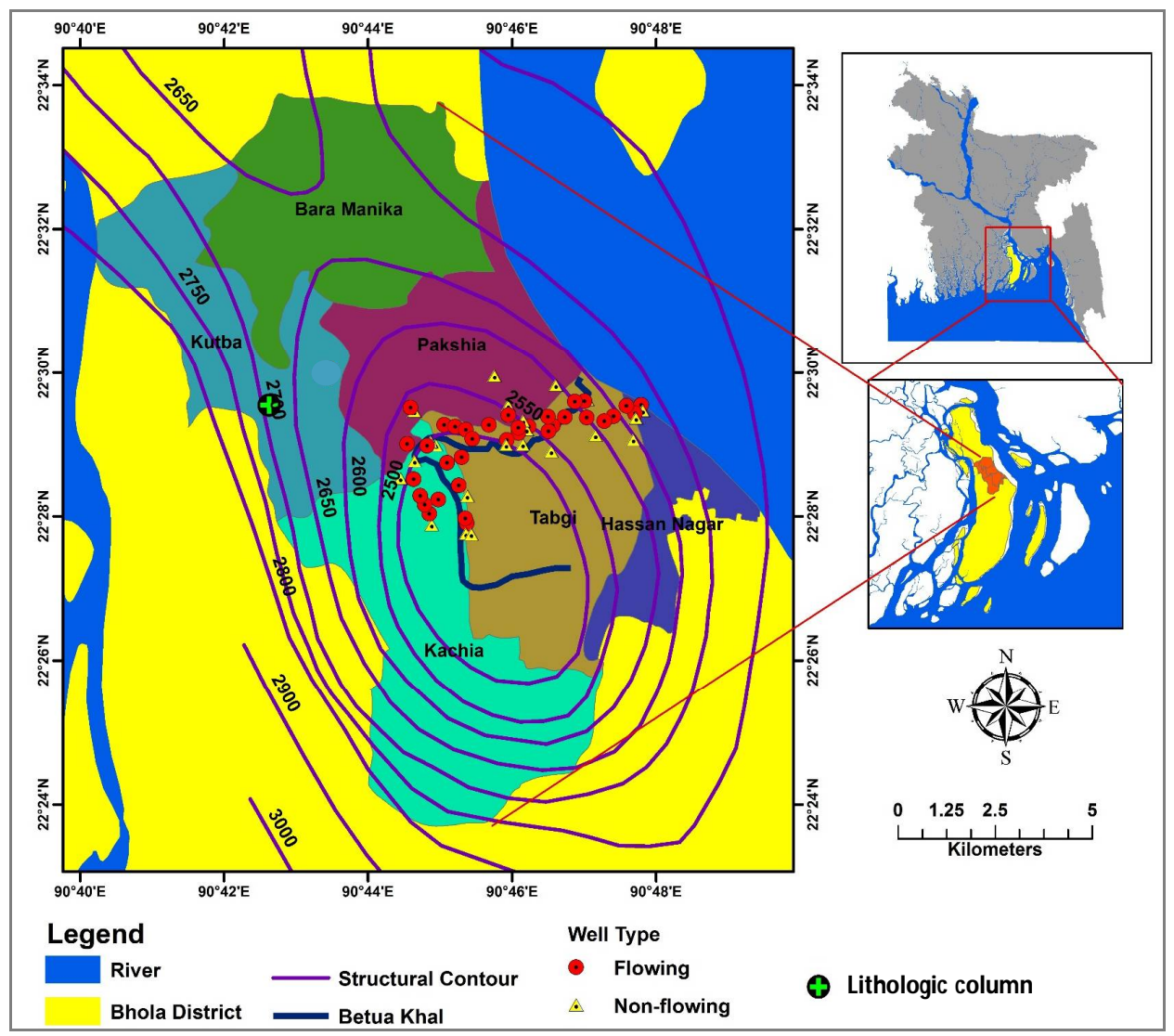

Fig. 1. Map of study area in Burhanuddin Upazilla, Bhola Island showing Shahbazpur anticline in purple contours and water sampling locations; yellow triangle for non-flowing wells (NFWs) and red circle for flowing wells (FWs) and lithologic column location green cross within black circle.

Therefore, the evaluation of hydrogeochemical properties of this strategically important source merits attention. Shallow groundwater in association with methane gas has been studied (Ahmed et al. 1998, Hoque et al. 2003) and most studies of the deep groundwater is confined to arsenic association (Shamsudduha et al. 2018, Hoque 2010, Burgess et al. 2010) and no study has been done so far on deep groundwater to methane gas association in Bangladesh. At this end, an attempt has been made to assess hydrogeochemistry of the deep groundwater and to compare the hydrogeochemical nature of FWs and NFWs in order to link them with methane gas association. 
The study area covered five unions i.e., Kachia, Tabgi, Kutba, Pakshia and Hassan Nagar of Burhanuddin Upazilla of Bhola Island, the largest offshore island in Bangladesh situated in the south eastern part at the mouth of Meghna river (Fig. 1). A natural khal named "Betua" is present nearly at center of the study area is a major geomorphic feature of interest (Fig. 1). In the subsurface of Bhola Island, Shahbazpur anticline is present where fluvio-deltaic sequence of Holocene age composed of fine to medium unconsolidated sand interbedded with clay layers and occasional presence of woody material extended up to $480 \mathrm{~m}$ depth (BAPEX 1995), Mondal et al. 2009, Rahman et al. 2016). This thick fluvio-deltaic sequence forms the aquifers viz. shallow, main and deep aquifers (BWDB-UNDP 1982) in the area where the deep zone is the depth of interest in this study. Deep seated gas has been discovered at a depth $>2500 \mathrm{~m}$ in Shahbazpur structure being produced commercially since 1995 (Mondal et al. 2009). On the other hand, the supply of methane gas through FWs is not limited but rather extensive which are deliberately constructed targeting deep aquifer within 225 to $290 \mathrm{~m}$ depth are composed of fine to medium sand and aimed to collect methane gas and water simultaneously. These FWs provide good quality of water as methane gas escapes immediately after reaching surface. The local people have been using this vented gas for household purposes through low tech local method since 1953 (BAPEX 2007) but frequently facing difficulties during well construction due to the presence of high pressure zones in the aquifer. The pressure of the gas in FWs is adequate to serve the households (BAPEX 1995).

\section{Materials and Methods}

Fifty nine groundwater samples from deep household tube wells (depth range 260 - $370 \mathrm{~m}$ ) have been collected for chemical analysis out of which 24 are from NFWs and 35 from FWs. Fig. 1 shows spatial distribution of sampled FWs and NFWs.

The onsite parameters i.e., EC, $\mathrm{pH}$, temperature were recorded in each location using portable EC and $\mathrm{pH}$ meter. Filtered acidified and unacidified samples were collected using standard methods and analyzed in the hydrogeochemistry laboratory at the Department of Geology, University of Dhaka. Concentration of cations (major and minor) were measured using Atomic Absorption Spectrophotometry and concentrations of anions i.e., sulphate and nitrate were measured by Ion Chromatography. Titration method was used to measure the concentration of bicarbonate. The quality of the sample analysis was checked by ionic balance and taken as $\pm 10 \%$ for hydrochemical assessment. Sediment samples (return wash samples during well drilling) were collected from one borehole installed by Department of Public Health Engineering (DPHE) in Kutuba union which is about 3 - $4 \mathrm{~km}$ away from the sampling periphery and lithologs have been produced by visual inspection (Fig. 8b). 
Moreover, total organic carbon (TOC) has been analyzed for the aquifer sand and underlying clay between $250 \mathrm{~m}$ and $285 \mathrm{~m}$ depth by Loss on Ignition (LOI) method. Data were compiled in excel spread sheet and analysis was done using hydrogeochemical software Aquachem 4.0. All the maps were produced using mapping software ArcGIS 10.1 .

\section{Results}

Variations of temperature and EC: Temperature of groundwater shows relatively higher values in FWs $\left(27-32.5^{\circ} \mathrm{C}\right)$ than the NFWs $\left(25.5-28.4^{\circ} \mathrm{C}\right)$ which may be due to chemical reaction during methane gas generation (Fig. 2a) and is not depth controlled. Electrical conductivity (EC) does not vary significantly between the two sampling groups but is shown to be relatively higher in FWs (Fig. 2b) ranging from 0.5 to $1.38 \mathrm{mS} / \mathrm{cm}$ whereas it ranges from 0.56 to $1.0 \mathrm{mS} / \mathrm{cm}$ in NFWs except one sample having EC of $1.31 \mathrm{mS} / \mathrm{cm}$.
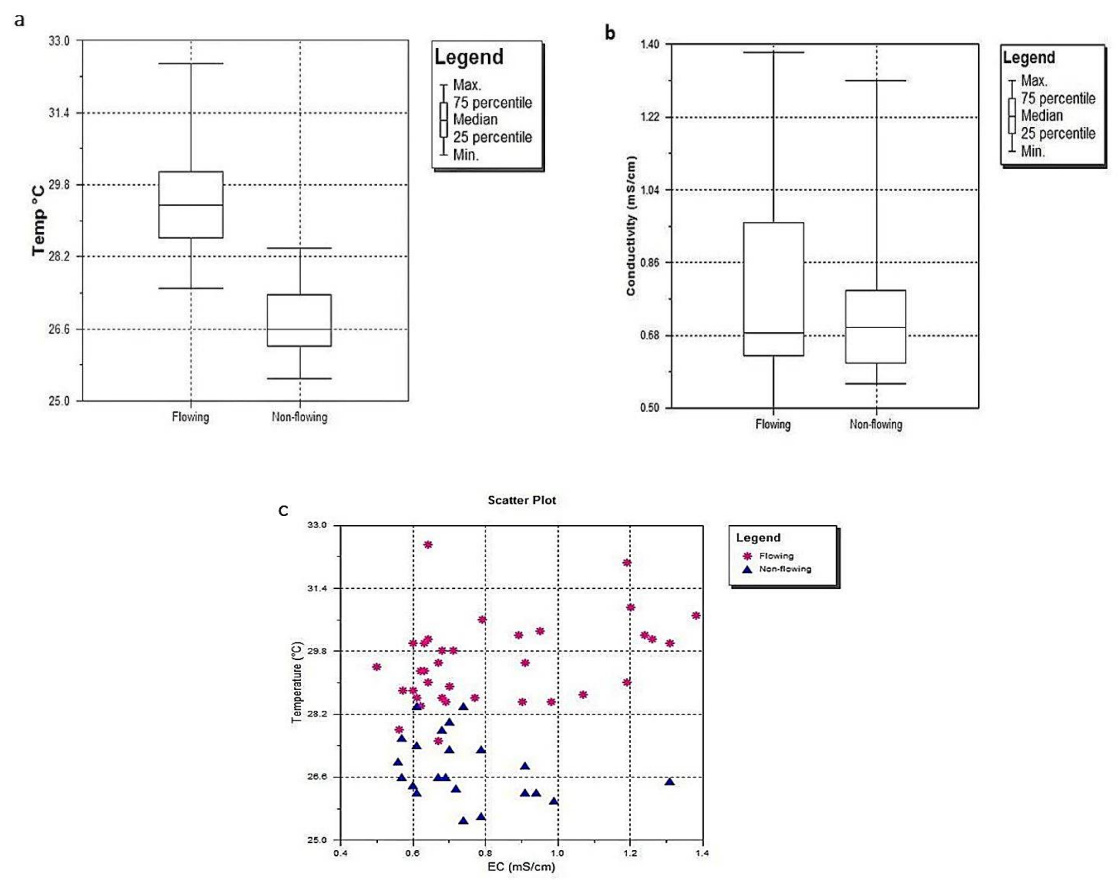

Fig. 2. Box and Whisker plot of temperature (a) and EC (b) in FWs and NFWs; Scatter plot EC and temperature (c) in FWs (shown as pink stars) and NFWs (shown as blue triangles).

Majority of samples from FWs are positively related to the temperature (Fig. 2c) (Freeze and Cherry 1979) and the reason of the counter intuitive relation for many wells in NFWs remains unknown. A noticeable spatial pattern of relatively high temperature and high EC is observed for FWs in eastern part of the sampling zone covering Kachia and Tabgi union (Fig. 3a,b). 


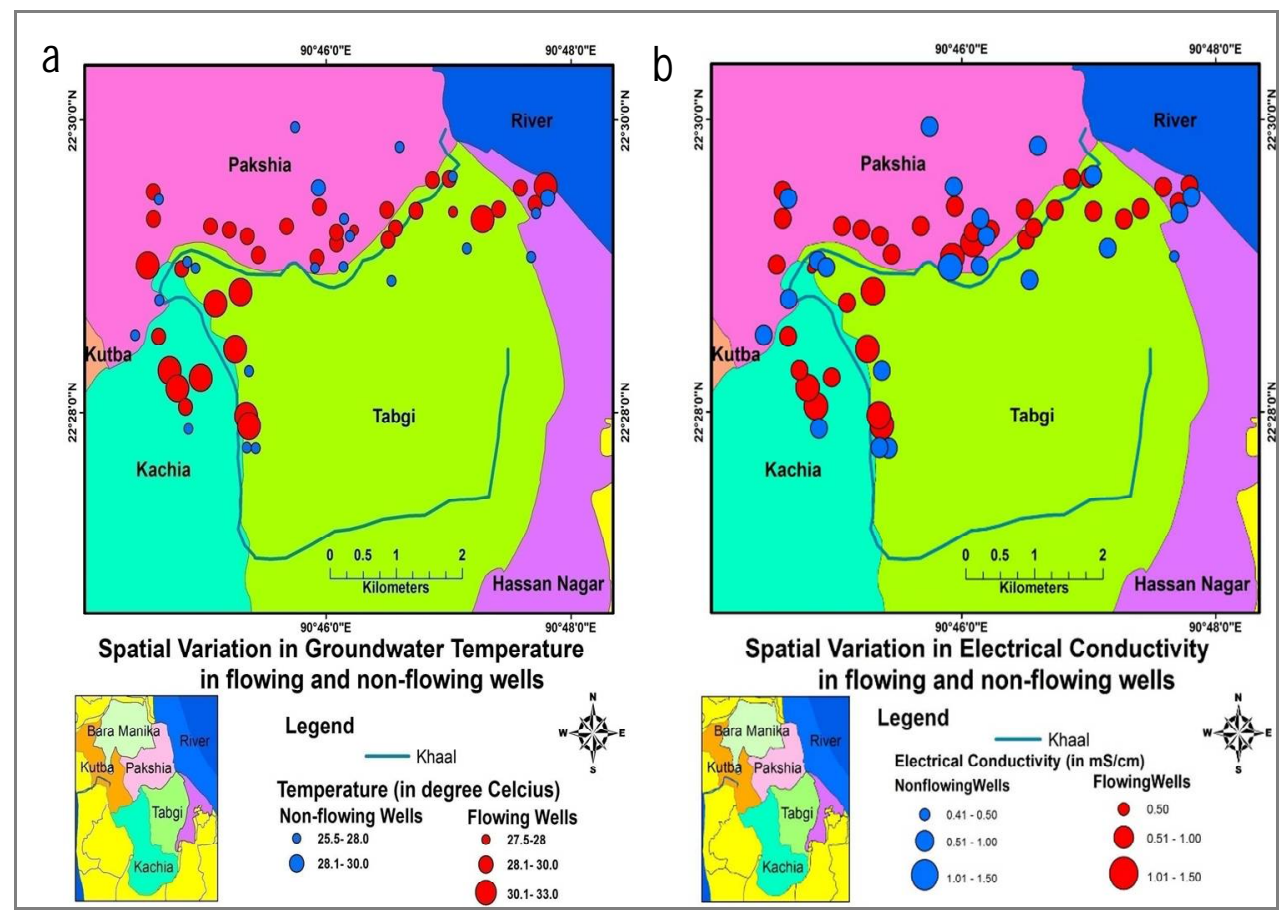

Fig. 3. Map showing spatial variation of temperature (a) and EC (b) in FWs and NFWs.

Variation in concentrations of major and minor ions: Relatively high $\mathrm{Na}^{+}$and $\mathrm{K}^{+}$ concentrations of deep groundwater (in both FWs and NFWs) in the study area adjacent to the Shahbazpur gas field pointing to reducing aquifer indicating the water with higher retention time which is further supported by low $\mathrm{Ca}^{2+}$ ion concentrations. Concentrations of $\mathrm{Mg}^{2+}$ ion in both FWs and NFWs are in similar range and generally are low (Table 1 and Fig. 4). On contrary, the concentrations of $\mathrm{HCO}_{3}{ }^{-}$ions in both $\mathrm{FWs}$ and NFWs are high suggesting oxidation of organic matter (Table 1). Minor ions like $\mathrm{Fe}^{2+}$ and $\mathrm{Mn}^{2+}$ play pivotal role in determining groundwater condition and the low concentration of $\mathrm{Mn}^{2+}$ concomitant with low concentration of $\mathrm{Fe}^{2+}$ both in FWs and NFWs (Table 1 and Fig. 6) indicates reducing condition. Low concentration of $\mathrm{Mn}^{2+}$ may be due to prevalence of reduced condition.

Among major cations, sodium and potassium have shown distinguishing variation between FWs and NFWs (Table 1). The median of $\mathrm{Na}^{+}$concentrations is $77 \mathrm{mg} / \mathrm{l}$ in FWs and is higher than the median of NFWs which is $65 \mathrm{mg} / \mathrm{l}$ (Fig. 4) and in both the cases majority of the samples lie above median. 
Table 1. Concentrations of major and minor ions in mg/l of FWs and NFWs.

\begin{tabular}{llll}
\hline & Ions & \multicolumn{1}{c}{$\mathrm{FW}$} & \multicolumn{1}{c}{$\mathrm{NFW}$} \\
\cline { 3 - 4 } & & \multicolumn{1}{c}{$(\mathrm{mg} / \mathrm{l})$} & \multicolumn{1}{c}{$(\mathrm{mg} / \mathrm{l})$} \\
\hline Major ion & $\mathrm{Na}+$ & $42.47-194.53$ & $47.89-187.55$ \\
& $\mathrm{~K}^{+}$ & $4.142-7.27$ & $4.27-6.75$ \\
& $\mathrm{Ca}^{2+}$ & $10.5-31.34$ & $10.44-36.84$ \\
& $\mathrm{Mg}^{2+}$ & $13.97-39.62$ & $13.97-47.17$ \\
& $\mathrm{HCO}_{3}{ }^{-}$ & $274.5-381.25$ & $289.75-373.63$ \\
& $\mathrm{NO}_{3}{ }^{-}$ & $0.005-0.18$ & $0.007-0.30$ \\
& $\mathrm{SO}_{4}{ }^{2-}$ & $0-0.18$ & $0.00-1.06$ \\
& $\mathrm{Cl}^{-}$ & $10.27-203.76$ & $3.9-210.98$ \\
Minor & $\mathrm{Mn}^{2+}$ & $0.01-0.091$ & $0.00-0.077$ \\
& $\mathrm{Fe}^{2+}$ & $0.012-1.38$ & $0.017-1.33$ \\
\hline
\end{tabular}

Similar observation applies for the concentration of $\mathrm{K} . ~ \mathrm{Cl}^{-}$concentration of groundwater in most of the FWs vary within a range of 10.27 to $199.02 \mathrm{mg} / \mathrm{l}$ with a median value 45.27 $\mathrm{mg} / \mathrm{l}$ except one sample having higher value (203.76 mg/l) (Fig 5).

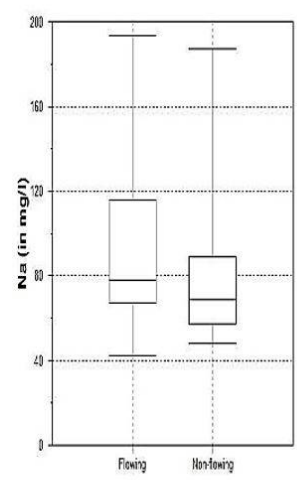

$\mathrm{Na}^{+}$

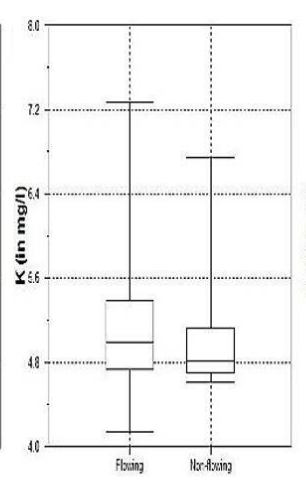

$\mathrm{K}^{+}$

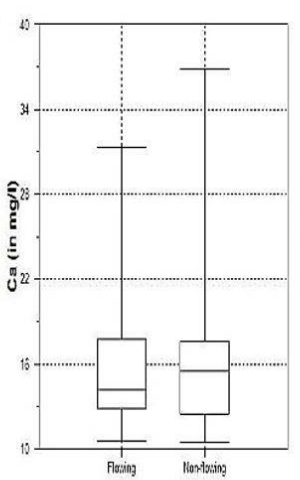

$\mathrm{Ca}^{2+}$

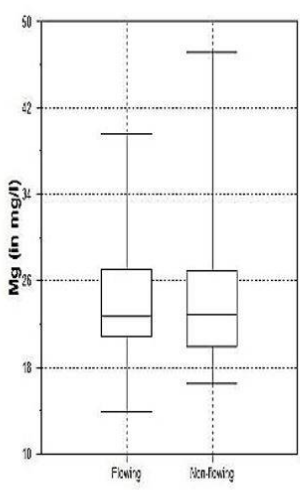

$\mathrm{Mg}^{2+}$

Fig. 4. Comparison of concentrations of major cations in $\mathrm{mg} / \mathrm{l}$ in FWs and NFWs.

On the other hand, the range is 3.9 to $126 \mathrm{mg} / \mathrm{l}$ in most of the NFWs except one sample having concentration $210.98 \mathrm{mg} / \mathrm{l}$ with a median value of $42.65 \mathrm{mg} / \mathrm{l} . \mathrm{NO}_{3}{ }^{-}$and $\mathrm{SO}_{4}{ }^{2-}$ ion concentration is below detection level in most of the cases except a few where both of them shows relatively higher concentration in FWs than NFWs. These undetectable and very low $\mathrm{NO}_{3}{ }^{-}$and $\mathrm{SO}_{4}{ }^{2-}$ concentration in the wells may be due to anaerobic ambience facilitating reduction reactions (Table 1, Fig. 5). The concentration of $\mathrm{Fe}^{2+}$ and $\mathrm{Mn}^{2+}$ are also very low (Fig. 6). 

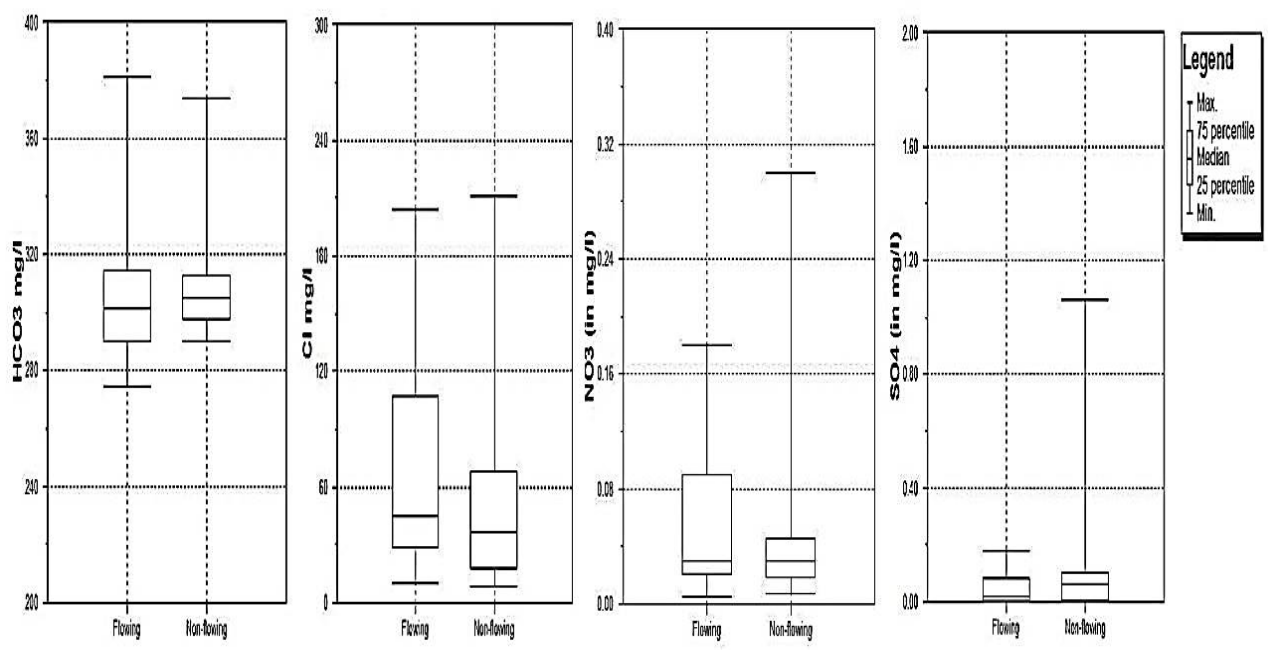

$\mathrm{HCO}_{3}{ }^{-}$

$\mathrm{Cl}^{-}$

$\mathrm{NO}_{3}^{-}$

$\mathrm{SO} 4^{2-}$

Fig. 5. Comparison of concentrations of major anions in mg/l in FWs and NFWs.
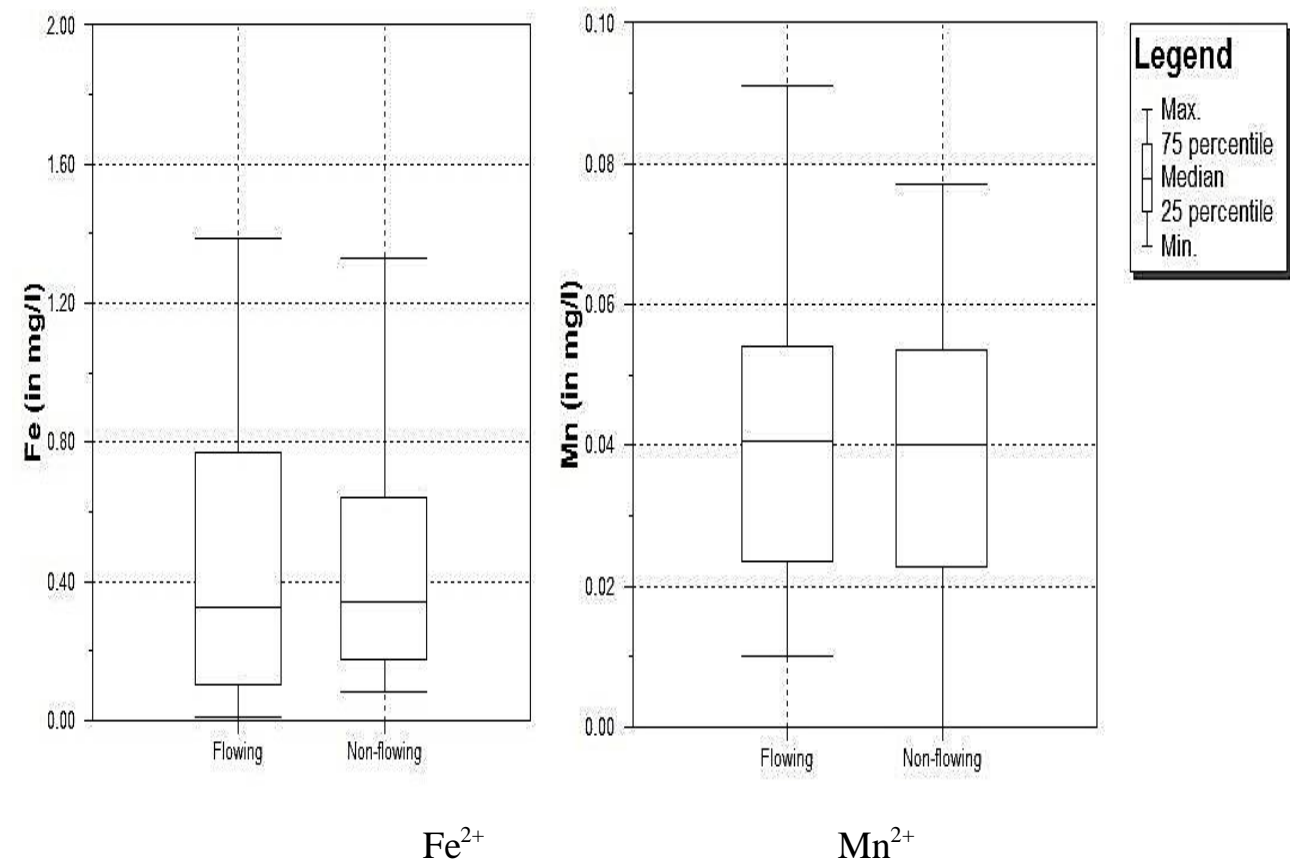

$\mathrm{Fe}^{2+}$

$\mathrm{Mn}^{2+}$

Fig. 6. Concentrations of $\mathrm{Fe}^{2+}$ and $\mathrm{Mn}^{2+}$ in $\mathrm{mg} / \mathrm{l}$ in FWs and NFWs. 
Hydrochemical facies: The chemical compositions of water slightly vary between FWs and NFWs. Na-Mg- $\mathrm{HCO}_{3}-\mathrm{Cl}$ type water dominate $(\sim 50 \%)$ in $\mathrm{FWs}$ whereas $\mathrm{Na}-\mathrm{Mg}-\mathrm{HCO}_{3}$ type is predominant $(\sim 50 \%)$ in NFWs (Fig. 7). About $40 \%$ samples show $\mathrm{Na}-\mathrm{Mg}-\mathrm{HCO}_{3}$ type water in FWs and nearly $40 \%$ samples are of $\mathrm{Na}-\mathrm{Mg}-\mathrm{HCO}_{3}-\mathrm{Cl}$ type in $\mathrm{NFW}$. There are a few wells which indicate occurrence of $\mathrm{Na}-\mathrm{HCO}_{3}-\mathrm{Cl}$ type water. Groundwaters types of $\mathrm{Na}-\mathrm{Mg}-\mathrm{HCO}_{3}-\mathrm{Cl}, \mathrm{Na}-\mathrm{Mg}-\mathrm{HCO}_{3}$ and $\mathrm{Na}-\mathrm{HCO}_{3}-\mathrm{Cl}$ in association with vanishing concentrations of nitrate and sulfate in reducing condition suggesting in situ methane formation under methanogenesis (Humez et al. 2016).

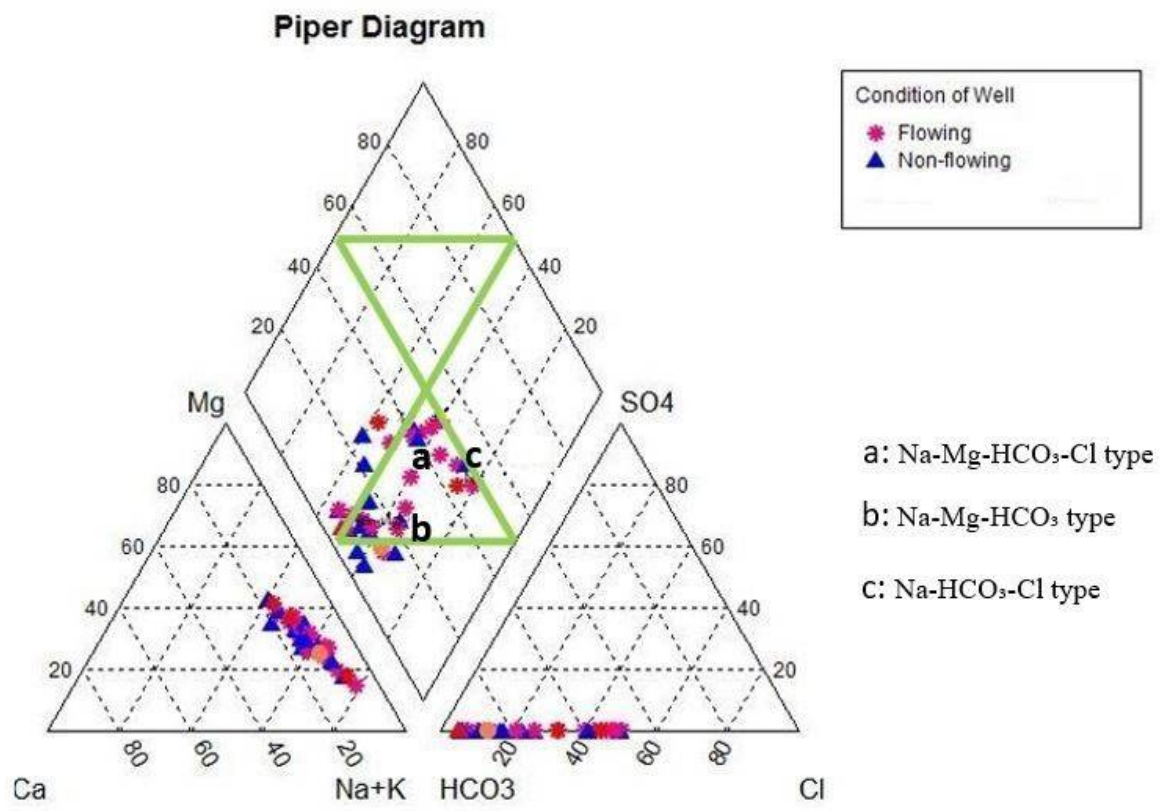

Fig. 7. Piper Diagram showing types of water in FWs and NFWs.

Redox ladder providing links to methanogenesis: It is suggested that enrichment of $\mathrm{HCO}_{3}{ }^{-}$ took place due to oxidative dissolution of organic matter present in the aquifer. The following reactions are likely to occur there:

$$
\begin{aligned}
& \mathrm{CH}_{2} \mathrm{O}+\mathrm{O}_{2}(\mathrm{~g})=\mathrm{CO}_{2}(\mathrm{~g})+\mathrm{H}_{2} \mathrm{O} \\
& \mathrm{CO}_{2}(\mathrm{~g})+\mathrm{H}_{2} \mathrm{O}=\mathrm{H}^{+}+\mathrm{HCO}_{3}{ }^{-}
\end{aligned}
$$

Chemical analysis of FWs and NFWs reveals low concentrations of redox sensitive parameters such as $\mathrm{NO}_{3}{ }^{-}, \mathrm{SO}_{4}{ }^{2-}, \mathrm{Fe}^{2+}$ and $\mathrm{Mn}^{2+}$ (Table 1) indicate prevalence of highly reducing environment (Fig. 8a). Redox ladder or oxidation-reduction reaction series can be 
a proxy to identify the origin of methane as microbial methanogenesis where $\mathrm{CO}_{2}$ reduction as its main formation pathway (Ahmed et al. 1998, Kulongoski et al. 2018).

Microbial reduction of sulphate and organic matter $(\mathrm{OM})$ in the sediment leads to the suitable environment for methane fermentation (Molofsky et al. 2013). The possible reduction reaction of sulphate and organic matter in the anaerobic environment of deep aquifer is as follows:

$$
\begin{aligned}
& \mathrm{CH}_{2} \mathrm{O}+\mathrm{SO}_{4}{ }^{2-}=\mathrm{HCO}_{3}{ }^{-}+\mathrm{HS}^{-}+\mathrm{CO}_{2}+\mathrm{H}_{2} \mathrm{O} \quad \text { (I) (Ahmed et al. 1998) } \\
& \mathrm{CH}_{2} \mathrm{O}=\mathrm{CO}_{2}+\mathrm{CH}_{4} \quad \text { (II) (Zhang et al. 1997) }
\end{aligned}
$$

Though concentrations of $\mathrm{SO}_{4}{ }^{2-}$ is low both in FWs and NFWs, relatively lower concentrations of $\mathrm{SO}_{4}{ }^{2-}$ in FWs suggest microbial sulphate reduction reaching final stage of redox ladder i.e., stage of methane fermentation. (Fig. 8a).

The catalyzing action of the anaerobic bacteria was also identified on site of FWs by the rotten egg smell of $\mathrm{H}_{2} \mathrm{~S}$ gas. The reaction incorporated in generation of $\mathrm{H}_{2} \mathrm{~S}$ gas is:

$\mathrm{HS}^{-}+\mathrm{H}^{+}=\mathrm{H}_{2} \mathrm{~S}$

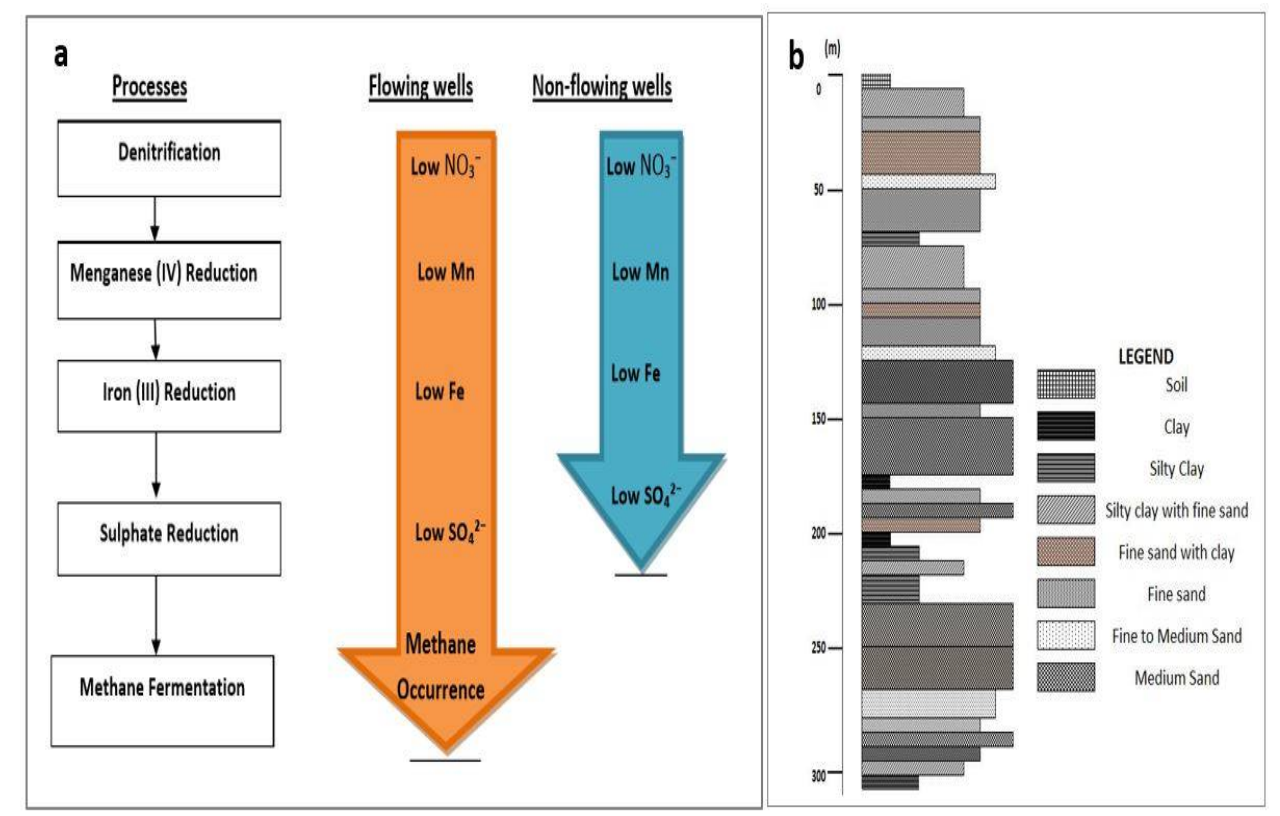

Fig. 8. (a) Redox Ladder showing the stages of reduction reactions in the aquifers for FWs and NFWs and (b) lithologic-column from DPHE test well in Kutuba union, Burhanuddin Upazilla. (Location shown in Fig. 1). 
The lithological column (Fig. 8b) indicates a sequence of gray coloured unconsolidated fine to medium sand interbedded with silty clay and clay layers indicating low degree of compaction and forms three cycles of sedimentation (fining upward). No woody material was found as mentioned in literature (BAPEX 1995, Mondal et al. 2009, Rahman et al. 2016) may be either due to the distant location of the well used for litholog generation from the sampling periphery or due to generation of litholog from wash samples which cannot catch single details of subsurface variation.

Deeper layer of silty clay at $236 \mathrm{~m}$ separating the upper sequences from the lower sequences may be acting as the confining layer above the deep aquifer in which all the FWs and NFWs are screened where the presence of FWs themselves are proof of confined and/or artesian aquifer. Lack of oxygen supply by being limited/no vertical recharge in such depth provides this deep confined aquifer zone suitable anaerobic atmosphere for methanogenesis.

Though wood particles were not found, some blackish particles were observed in sand samples at depth between 250 and $285 \mathrm{~m}$. The measured TOC content of these samples is $\sim 0.04$ and underlying clay is 0.11 which is almost one order of magnitude lower than the required amount $(0.5 \%)$ for any hydrocarbon generation (Tissot and Welte 1984).

Most of the FWs are located in the axial region of Shahbazpur gas field along "Betua Khal" a major geomorphic feature indicative of existence of paleo-valley (Molofsky et al. 2016) that have been shifted and subsided over the past geologic time. Low geothermal gradient $(2<2.5 \mathrm{k} / 100 \mathrm{~m})$ have been reported (Kabir 2007) for the region despite being an area of thermogenic gas reserve. FWs have been tested several times by BAPEX to find any clue about seepage from the thermogenic gas reservoir. No evidence of fracture has been reported so far in 2250m vertical profile of Shahbazpur structure (BAPEX 1995) to validate possibility of thermogenic gas migration from the mega-reserve present at a depth of $>2500 \mathrm{~m}$ (Mondal et al. 2009) to FWs constructed at $\leq 320 \mathrm{~m}$ depth. The composition of the gas of FWs as identified by its flammable characteristics is pure methane occasionally associated with little higher hydrocarbons (BAPEX 2007). Generally, biogenic gas contains $>98.5 \%$ methane and a little ethane gas (Tissot and Welte 1984). The $\mathrm{C}_{1} / \mathrm{C}_{2}$ ratio of gas samples from FWs of Burhanuddin Upazilla is 1200 - 3500 whereas the ratio is 20-35 for the deep thermogenic gas produced from Shahbazpur Well-1 (Rahman 2015) also supports the biogenic origin of collected methane gas. The dryness of the gas $(\sim 1)$ shows very little possibility of mixing of thermogenic gas as the thermogenic gas tends to have moderate dryness values (Rahman 2015). Moreover, the widespread occurrence of methane in FWs was well known even before the completion of deep thermogenic gas well i.e., Shahbazpur \#1 (BAPEX 1995). More study is needed to ascertain the spatial correlation between these two phenomena. 
The mechanism responsible for methane gas occurrences in FWs mentioned above "methanogenesis" in deep reducing aquifer zone where it reaches final stage of reduction reaction series sulphate being reduced by microbial activity and consequently produces "biogenic gas" methane. Aquifer type i.e., deep confined aquifer, depth of burial, presence of OM, geothermal gradient and water type i.e., dominancy of $\mathrm{Na}-\mathrm{Mg}-\mathrm{HCO}_{3}$ water in $\mathrm{FWs}$ being distributed over a paleo valley are referring to the existence of favourable environment to methanogenesis rather than the upward migration or leakage of thermogenic methane concomitant with gas field in the region.

Isotopic study i.e., stable isotopes are highly recommended to deduce the age of the groundwater. $\delta 13 \mathrm{C}_{\mathrm{CH} 4}$ study is a good option to ascertain the origin of the gas (biogenic or thermogenic) or deduce $\mathrm{C}_{1} / \mathrm{C}_{2}$ ratio of $\mathrm{FW}$ s otherwise.

\section{Acknowledgements}

The authors are grateful to BAPEX for unflinching support during fieldwork and to Department of Geology, University of Dhaka for providing laboratory facilities. Support of DPHE in sediment sample collection is much appreciated.

\section{References}

Ahmed, K.M., M. Hoque, M. K. Hasan, P. Ravenscroft, L.R. Chowdhury. 1998. Occurrence and origin of water well methane gas in Bangladesh. J. Geol. Soc. of India. 51: 697-708.

BAPEX. 1995. Geological Report on Shahbazpur Structure. Unpublished report.

BAPEX. 2007. Report on shallow gas occurrence in Bhola Island. Unpublished report.

Bernard, B. J., J. Brooks, W. Sackett. 1976. Natural gas seepage in the Gulf of Mexico, Earth and Planetary Sciences Letters 31: 48-54.

Burgess, W. G., M. A. Hoque, H. A. Michael, C. I. Voss, G. N. Breit, and K. M. Ahmed. 2010. 'Vulnerability of deep groundwater in the Bengal Aquifer System to contamination by arsenic. Nature Geoscience 3: 83-87.

BWDB .2013. Establishment of Monitoring Network and Mathematical Model Study to Assess Saline Water Intrusion in Groundwater in the Coastal Area of Bangladesh due to Climate Change. Final Report, Bangladesh Water Development Board and Institute of Water Modelling. 1-6 Package 3.

BWDB-UNDP. 1982 Groundwater Survey: The Hydrogeological Conditions of Bangladesh. UNDP Technical Report DP/UN/BGD-74-009/1.

Delaune, R. D., C.J. Smith and W.H. Patrick. 1986. Methane production in Mississippi River deltaic plain peat: Organic Chemistry 9: 193-197.

Freeze, R. A., and J. A. Cherry. 1979. Groundwater, Prentice Hall Inc. Englewood Cliffs, New Jersey.

Hoque, M. A. 2010. Models for managing the deep aquifer in Bangladesh (Ph.D. thesis), University College London. 
Hoque, M., M. K. Hasan and P. Ravenscroft. 2003. 'Investigation of Groundwater Salinity and Gas Problems in Southeast Bangladesh.' in A. A. Rahman and P. Ravenscroft (eds.), Groundwater resources and development in Bangladesh - background to the arsenic crisis, agricultural potential and the environment (Bangladesh Centre for Advanced Studies, University Press Ltd.: Dhaka).

Humez, P., B. Mayer, M. Nightingale, V. Becker, A. Kingston, S. Taylor, G. Bayegnak, R. Millot and W. Kloppmann. 2016. Redox controls on methane formation, migration and fate in shallow aquifers, Hydrol. Earth Syst. Sci. 20: 2759-2777.

Imam, B., 2015. Energy Resources of Bangladesh. $2^{\text {nd }}$ edition.

Kabir, S. M. M. 2007. Subsurface temperature and geothermal gradient in Bangladesh.MS thesis, University of Dhaka, Bangladesh.

Kulongoski, J.T., P.B. McMahon, M. Land, M.T. Wright, T.A. Johnson and M.K. Landon. 2018. Origin of methane and sources of high concentrations in Los Angeles groundwater. $J$. of Geophy Research: Biogeoscience 123: 813-831.

Mondal D.D., M. Islam and A. Islam. 2009. Electrofacies Analysis of Neogene Sequence in the Well Shahbazpur-1, Bhola, Bengal Basin, the IUP J. of Earth Sciences 5.1: 57-74.

Molofsky, L.J., J.A. Connor, T.E. McHugh, S.D. Richardson, C. Woroszlyo and P.J. Alvarez. 2016. Environmental factors associated with natural methane occurrence in the Appalachian Basin, Groundwater. 54(4): 656-668.

Molofsky, L.J., J.A. Connor, A.S. Wylie, T. Wagner and S.K. Farhat. 2013. Evaluation of methane sources in groundwater in northern Pennsylvania: Groundwater. 52.3: 333-349.

Rahman, M., 2015. Occurrence and Distribution of Shallow Gas in Southern Bangladesh: A Case Study on Bhola Island. M.S. Thesis, Department of Geology, University of Dhaka, Dhaka, Bangadesh. (Unpublished).

Rahman, M., S.M. Kabir and J. Hakim. 2016. Shallow gas prospect evaluation in Shahbazpur Structure using seismic attributes Analysis - A case study for Bhola Island. Southern Bangladesh. Dhaka University Science J. 64(2): 135-140.

Ridgeley, J. L., T. C. Hester, S. M. Condon, T. Cook, O. L. Anna, P. G. Lillis, E. L. Rowan and G. T. Snyder. 2001. ABSTRACT: Assessment of shallow biogenic gas resources in Montana: CSPG Special Publications: 284-289.

Shamsudduha, M., A. Zahid, and W. G. Burgess. 2018. Security of deep groundwater against arsenic contamination in the Bengal Aquifer System: A numerical modeling study in southeast Bangladesh. Sustainable Water Resources Management. Springer.

Tissot, B.P. and D.H. Welte. 1984. Petroleum Formation and Occurrences. 2nd revised and enlarged edition. Springer-Verlag.

Zhang, X. C., Lin, C. M., Li, Y. L., Qu, C. W. and Wang, S. J. 2013. Sealing mechanism for cap beds of shallow-biogenic gas reservoirs in the Quiantang River incised valley. China: Continental Shelf Research 69: 155-167.

Zhang, G., Zhang, J., Liu, S., Ren, J., Ju, X. and Zhang, F. 2008. Methane in the Changjiang (Yangtze River) estuary and its adjacent marine area: riverine input, sediment release and atmospheric fluxes, Springer, Biogeochemistry, October 2008, 91.1: 71-84.

Zhang X.C., Ethan, I., Grossman, L. and Ammerman, J.W. 1997. Factors influencing methane distribution in Texas ground water, Organic Chemistry 3: 283-288. 